\title{
All about Iraq: Re-modifying older slogans and chants in Tishreen [October] protests
}

\begin{abstract}
This paper analyses five main slogans and chants performed during the first three months of Iraq's 2019 Tishreen [October] protests. It aims to trace their origin to examine the transformation in the narratives created by each version. Drawing on a social approach to narrative and a social semiotic multimodal approach to communication, I treat slogans and chants as an evolving genre and performance, capable of triggering, constructing, and negotiating a different set of narratives in each adaptation. Such narratives arguably determine their impact. Unlike earlier versions, Tishreen chants and slogans succeeded in conjuring up collective and cross-sectarian narratives that could challenge master political narratives and heighten an Iraqi identity in the first place. It would, therefore, be hard to erase them from memory.
\end{abstract}

\section{Introduction}

The idea behind writing this paper first emerged back in December 2019. As an activist, I was translating from afar the slogans raised by Iraqi protestors during the first three months of the 2019's protest movement, known in Iraq as Thawrat Tishreen [October Revolution] and sharing them on my social media account as a scholar-activist. ${ }^{1}$ Despite the immediate and violent crackdown against the protestors, what started as a small protest movement on 1 October quickly 'snowballed into a countrywide mobilisation that involved all of Iraq's central-southern provinces on 25October' (Lovotti and Proserpio, 2021: 645). According to

\footnotetext{
${ }^{1}$ In this paper, I use revolution, protest and uprising interchangeably to refer to Thawrat Tishreen.
} 
Iraqi academics, journalists and observers (e.g. Hasan, 2020; Nadhmi, 2020; Al-Shams, 2021a; Cornish 2019; Rubin 2019), the Tishreen uprising was the largest and most influential protest movement in Iraq's contemporary history.

Framed within the prominent slogan of 'Nureed Watan' [We Want a Homeland], the chants marked a remarkable shift from the sectarian discourse generated by post-2003 ruling parties. Furthermore, they departed from past political and sect-centred narratives, reconstructing a national identity shattered by the post-2003 ethno-sectarian Muhasasa [quota] system. Indeed, the new rhetoric played a crucial role in mobilising others to join the movement, resonating with Iraqi diasporas as well (Lovotti and Proserpio, 2021).

As an Iraqi academic and activist, I could not resist thinking about the sources of these slogans. Where did they come from? And why were they able to appeal to many Iraqis? Bridging the gap between scholarship and activism, I wanted to be involved in this critical historical moment by documenting its most important chants and creating an academic space to reflect upon their significance critically and emphatically.

Slogans have gained noticeable academic attention (e.g. Denton, 1980; Sharp, 1984; Lu, 1999). Different scholars have attempted to study their various functions. For example, Denton (1980) and Sharp (1984) have examined their use in the political discourse. Lu (2004) and Kaul (2010), among many others, have focused on the ideologies constituted by slogans. Many studies have explored their rhetorical function (e.g. Bitzer, 1981; Billig 1991, 1995; Lu, 1999). Several scholars have analysed slogans raised during the Arab Spring uprisings, particularly the Egyptian Revolution (e.g. Colla, 2013; Lahlali, 2014; Carle, 2021). Al-Haq and Hussein (2012) have studied four hundred slogans collected from different protests squares in Tunisia and Egypt, drawing on a sociolinguistic approach. Al-Sowaidi et al. (2017) have undertaken the first detailed political discourse analysis on Arab Spring slogans chanted in various countries, examining their linguistic features. 
Studies on protests slogans in other countries, including Lebanon and Iraq, remain scarce. For example, Nassar and Al-Harahsheh (2020) explore the socio-pragmatic functions of 202 slogans raised by Lebanese protestors in 2019 and 2020. Srour (2021) has researched their ideological features drawing on van Dijk's (1997) Ideology Schema. As for the Iraqi protests, there is an emerging Arabic-language scholarship by Iraqi academics on the linguistic and rhetorical features of the slogans used during the 2015's protest movement and the 2019's October uprising (e.g. Mahmoud and al-Rawi, 2019; Al-Shams, 2021a; Al-Shams, 2021b; Atiya, 2021; Muhyi and Ali, 2021). English-language research is still lacking. An exception is a recent work by Lovotti and Proserpio (2021), which interviews some of the activists who participated in the first wave of the protests to investigate the factors that shaped their decisions and led to different forms of spontaneous participation. In its final section, the paper sheds light on some of the protest slogans raised during the 'early moments' of the uprising.

Therefore, my paper provides an original contribution to English-language literature on Iraqi studies and social movements by offering an in-depth analysis of the protests' most powerful chants and tracing their origins to examine how they change over time. I will do so by viewing chants and slogans as performances, which evolve as a genre without necessarily having the same impact in each modification. Drawing on a social approach to narrative (Somers, 1992; Somers, 1994; Somers and Gibson, 1994; Baker, 2006), I analyse the different narratives established by each version. My data set was collected from various online sources, including YouTube videos, news articles, Facebook posts, and tweets. Throughout the paper, I also refer to other slogans and use international organisations and media reports as secondary sources to evidence my claims.

The primary rationale behind choosing these chants pertains to their circulation and transformation across different times and places. These slogans/chants constituted collective 
and cross-sectarian narratives in their most recent editions, subverting the religious and political narratives triggered by earlier versions and reconstructing new national identities. Furthermore, each of the five chants has played a vital role in mobilising other people to join the protests, whether through their live performances or later dissemination via social media platforms. There are, of course, countless other slogans or chants that deserve to be thoroughly researched. My paper, thus, calls for other researchers to focus their attention on Iraqi protests' slogans/chants in their future studies. Since research on Iraq in the post-2003 context has primarily adopted a top-bottom approach, time is now due to turn our attention to bottom-top approaches to emerging Iraqi studies.

The article will proceed as follows. First, it will present an overview of Tishreen slogans/chants underpinned by the theoretical assumptions that will guide the data analysis. It will then provide a background to Tishreen protests and the events leading up to October 1 . The last section will investigate the narratives established by the chants under scrutiny.

\section{Tishreen slogans/chants as an act of performance}

Tishreen protests were known for the abundance of slogans and chants raised to challenge the status quo (Al-Shams, 2021a, 2021b). These were communicated in a variety of modes, including the written, spoken and visual. Demonstrators also combined classic Arabic, Iraqi dialect and English language to deliver their messages to diverse audiences. However, Iraqi dialect characterised most of the slogans/chants, contributing to their familiarity and wide dissemination among Iraqis (Al-Shams, 2021a).

Slogans and chants are often used interchangeably in the literature (e.g. Colla, 2013; Nassar and Al-Harahsheh, 2020; Carle, 2021). Despite the overlap between the two, a distinction is

still necessary, especially in the Iraqi context, for reasons I will explain later. The word slogan is derived from the Gaelic slaughghairm, which means 'army cry' or 'war cry' (Sharp, 
1984 cited in Al-Sowaidi et al., 2017: 622). Slogans are shorter than chants and can be communicated through different mediums, including 'banners, wall graffiti, audio-visual instruments, chanting, speeches and songs' (Al-Sowaidi et al., 2017: 622). For example, Nureed Watan [We want a homeland] mentioned in the introduction was the protests' prominent slogan. According to an activist interviewed by Lovotti and Proserpio (2021), the slogan was inspired by a TV interview with an older man who was in the protests square in Baghdad on October 1. When asked about what he and other demonstrators wanted, his response was, 'we don't want anything, we just want a homeland'. According to the activist, 'That answer went so viral that it became the motto for the [2019] October revolution' (Lovotti and Proserpio, 2021: 656). The slogan was a short yet effective phrase that powerfully captured the collective grievances of all Iraqis, no matter their background or secondary identities. Another famous slogan identifying Tishreen protests was Nazil akhuth haqi [I am taking into the streets to reclaim my right]. It reflected a shared deprivation and class struggle, which went hand in hand with the Iraqi national identity expressed in Nureed Watan (Nadhmi, 2020). The slogan reverberated across Iraq, became a popular hashtag on Iraqi Twitter, and was shortly adapted into a song associated with the Tishreen uprising. ${ }^{2}$ Therefore, slogans carry the same characteristics of chants when chanted, blurring the boundaries between the two.

The etymology of the word 'chant', on the other hand, demonstrates that the term is derived from the Latin cantare, meaning 'to sing'. ${ }^{3}$ Chants always involve sound, rhythm, and singing (Manabe, 2019). Following Jakobsen (1978), I view chants as genres of a specific discourse. Furthermore, I draw on a social semiotic multimodal approach to communication (Kress, 2009) to stress the dynamic changing nature of genres as they set up new processes between the participants themselves. As Miller (2015) reminds us, a particular genre is

\footnotetext{
${ }^{2}$ See Rahma Riad - Nazel Akhud Ha'i (2019) / رحمة رياض - نازل أخذ حقي - YouTube 3 See chant | origin and meaning of chant by Online Etymology Dictionary (etymonline.com).
} 
socially and culturally recognised and perceived. In other words, genres constantly evolve and cannot be static (Kress, 2009; Lüders et al., 2010). In Iraqi culture, there are various types of chants. For instance, hosa or 'aradha is a poetic chant that emerged in the south of Iraq and was used during tribal conflicts and wars to instil enthusiasm among people. Hosa is improvised and performed by a talented person, known as al-Mihwaal, who starts the chants with the phrase 'ha khouti ha' [Oh, my brothers, repeat after me!]. There is also Ihzooja, which is very similar to songs but often sung by a group of people (Al-Khalidi, 2021). War songs are sometimes referred to as Ahazeej [plural form of Ihzooja] or Anasheed [plural of Inshooda]. All sub-genres of Iraqi chants have evolved historically. Al-Khalidi (2021) notes that hosa, for instance, has merged with poetry and songs. Tishreen chants are often described as either hosat [plural of hosa] or Ahazeej. They combine Hamasa [Zeal] poetry, which revolves around solidarity, support and persistence and Hija [diatribe poetry] (Colla, 2013) directed against ruling parties.

Slogans and chants are more than just 'linguistic texts' (Colla, 2013: 38). Many scholars view them as an act of collective embodied performance (e.g. Ismail, 2011; Colla, 2013; Butler, 2015; Aulich, 2020; Carle, 2021). Performances constitute the 'aesthetics of the protests' that cannot be detached from politics (Aulich, 2020). Butler (2015: 11) highlights this relationship between aesthetics and politics when she writes about live performances' ability to place 'the body in the midst of the political field', delivering 'a bodily demand for a more liveable set of economic, social, and political conditions'. Aulich (2020: 271) illustrates how chanting in the moment creates an intensity and 'a cacophony that engages our interest, seduces our feelings, produces our reality and demands responsibility in action' (Aulich, 2020: 271). Chanting in the face of danger adds another layer of intensity and urgency because it reveals protestors' bravery and determination, inviting others to join the crowds. Iraqi demonstrators were targeted by live ammunition and snipers (See Amnesty, 2019b), but they relentlessly 
continued to voice their outrage and demands through chants. As Jasper (1997) argues, repression can be morally shocking and may likely provoke people to be involved in further political action (Also refer to Lovotti and Proserpio, 2021).

The impact of chants is not limited to the present moment. They can have a long-lasting effect when they are recorded and disseminated through social media. Aulich (2020: 272) calls this process 'the aesthetics of the trace of the demonstrations in analogue and digital media, the imagination and memory, and their distribution systems and wider cultural contexts'. Recording, filming and circulating chants on the internet is at the heart of their production and performance. In her study of the Egyptian Revolution slogans, Colla (2013) shows us how Egyptian activists deliberately chose to record and disseminate their performances online. Despite the violent crackdown on Iraqi protestors, they similarly insisted on filming their performances and distributing them on social networking sites to empower their message and reach a wider audience. The circulation on social media also gives protestors 'an astonishing resilience and morale' (Tunali, 2018: 389). Moreover, it helps the performances to be recalled and remembered.

But what are the sources of chants and slogans? Carle (2021: 16) maintains that performances draw from a shared 'heritage and a popular culture' that includes songs, religious texts, older slogans, political speeches, etc. Since the majority of the Iraqi protestors were Shia Muslims, most of their chants were inspired by Shia-centered slogans and Ashura religious rituals. ${ }^{4}$ Furthermore, some chants were an inspiration of the Iran-Iraq war enthusiastic, patriotic songs or Ahazeej. A question may arise here: how was it possible for the demonstrators to reuse chants that could be problematic for other segments of the Iraqi population- whether due to their links with the Saddam regime or a particular sectarian identity?

\footnotetext{
${ }^{4}$ The Day of Asura marks the death of Imam Hussein, Prophet Muhammed's grandson, at Karbala Battle. It is commemorated by Shia Muslims on the $10^{\text {th }}$ of Muharram, the first month of the Islamic lunar calendar.
} 
To answer this question, Tilly's (2008) concept of 'repertoire' helps explain how chants/slogans can evolve and change meanings. Rather than being spontaneous, public performances are scripted and incrementally improvised and revised (Tilly, 2008; Colla, 2013) whilst their authors remain anonymous (Al-Sowaidi et al., 2017). Tilly (2008) calls this process 'repertoire', which entails multiple performances tried and tested repeatedly. A single version is, thus, insufficient for turning one slogan or chant into a repertoire (Colla, 2012). In the short term, performances remain limited in their ability to change and transform (Tilly, 2008).

Chants, thus, represent 'historically grounded performances' (Tilly, 2008: 4) that require repetition over time to become recurrent. For a slogan or a chant to resonate among people, it must be familiar and easy to recognise, recall, and memorise (Carle, 2021) but can always be modified and amended to fit new contexts (Colla, 2013). Chants of religious or political nature were familiar to Iraqi protestors, who managed to revise and modify them by removing any sectarian or former Baathist regime references, replacing them with new and positive vocabularies that changed the narratives linked with their sources. However, it was not always possible to avoid controversy, especially in the case of Iran-Iraq war songs, as discussed later in the paper.

In other words, the newly adjusted chants mediated the original versions and dismantled their narratives. I use mediation here following Grusin (2016: 126) to refer to any physical or material 'object, event, or process in the world, impacting humans and nonhumans alike'. Through this mediation, the new narratives echoed by Tishreen chants constructed a new reality and identity (Somers, 1992; Somers and Gibson, 1994). They were able to do so because they changed the defining features of older narratives: their relations with other events, actors and identities (relationality), the reasons why they had their specific storylines 
(causal emplotment), and their sequence (temporality) by including and excluding particular vocabularies (selective appropriation) (Somers, 1994: 616).

Before investigating the new narratives, it is first necessary to contextualise Tishreen Revolution by placing it with other local and regional protest movements to understand the shifts in their slogans and narratives.

\section{A background to Tishreen Uprising}

Although the Tishreen protest movement can be thought of in terms of other local, regional and international movements worldwide, it is crucial to highlight its uniqueness. Unlike the authoritarian context of Arab Spring uprisings, for instance, Tishreen protests emerged within a context of a hybrid regime in which elements of political competition mix not only with totalitarian practices (Robertson, 2011) but also with Islamist oligarchy, theocracy, kleptocracy, and multiple parties with armed groups (Mustafa, 2019; Hasan, 2020; Nadhmi, 2020). The post-2003 ethno-sectarian Muhasasa system, rampant corruption in Iraqi institutions, and the weak rule of law have had political and social repercussions. These structural conditions have contributed to a fragile Iraqi state and a climate of political turmoil and instability in Iraq attested by the 2006-2007 civil conflict and the rise of the terrorist group Islamic State in 2014 (Mabon, 2017). They also helped fragment the Iraqi national identity favouring secondary sectarian or ethnic identities (Hasan, 2020; Nadhmi, 2020).

In such context, waves of demonstrations have occurred in Iraq since 2011 for almost the same reasons: seeking fundamental rights, functional governance, social justice, and calling to address corruption and unemployment. Even though similar motives drove each protest episode, they diverged in their organisation and slogans. Unlike the 2011's protest cycle, which was led by the Iraqi intellectual elite, the 2015 's protest wave started as a grassroots 
movement. Still, it was later exploited by political parties and figures, particularly the controversial religious figure and al-Mahdi Army militia leader Muqtada al-Sadr (Ali, 2021). In 2011, demonstrators denounced the corruption, sectarianism, and nepotism that characterised Nouri al-Maliki's government (Al-Rawi, 2014). Their main slogans were Jathab Nouri al-Maliki (Nouri al-Maliki is a Liar), Kala lil fasad [No to Corruption] (AlRawi, 2014: 917). In 2015, there was a shift in the Iraqi protests' demands characterised by the new slogans of bism al-din bagona al-haramiya [In the name of religion, the thieves have stolen us], and Khubz, Huriyya, Dawla Medeniyya [Bread, Freedom, and a Civil State] (Ali, 2021: 4). Instead of a call against corruption, there was a rise against the whole religiouspolitical establishment (Ali, 2021).

In 2018, another wave of protests erupted first in the oil-rich province of Basra in the south before spreading to other areas. Contrary to the previous two movements, the 2018's protest cycle unfolded as spontaneous, organic, and leaderless. Initially driven by water shortage in Basra province and constant power cuts amid unbearable heatwaves, the demonstrations quickly transformed into a rising against the post-2003 status quo (Mustafa, 2018). One of its main chants was nmut 'ashara, nmut miya, any qaful 'al qadhiya [10 of us would die, or 100 of us would die, I won't give up the cause]. The chant reflected the persistence and resilience of the demonstrators in the face of state-sanctioned violence. It was adapted during the Tishreen protests (more on this in the following section).

The protest timing was significant as it followed Iraq's general elections, boycotted by the majority of Iraqis, which revealed the deepening gap between the people and the political class as a whole. Growing anger over political parties was translated into concrete action as demonstrators burnt their headquarters and offices in several provinces in the south. Simultaneously, the protest marked a mounting fury over Iran's interference in Iraq's affairs as Shia protestors highlighted the 'Iraqiness' of their identity 'as opposed to political leaders, 
whom they see as loyal not to Iraq but to an interfering Iran' (Mustafa, 2018). Like the previous episodes, 2018's demonstrations were violently repressed (Ali, 2021).

Tishreen uprising can be seen as a continuation of Basra's protest movement. The Shia millennial generation formed the backbone of the two waves (Nadhmi, 2020). Although more significant in scope and more potent in its slogans, the Tishreen uprising was similar to the 2018's protests in its leaderless and decentralised nature. However, its timing was significantly different to past years' demonstrations. Rather than a response to frequent power cuts during the summer heat, the revolution occurred in October following cycles of localised smaller protests led by different people, including engineers, graduates, and doctors, who protested against unemployment or a dysfunctional health sector; respectively. The majority of these protests were suppressed by force (Mustafa, 2019).

October's protests also followed a campaign to demolish illegal houses and vendors' stalls in different provinces, including Karbala and Basra, causing outrage among the impoverished people. Moreover, the protest came in the aftermath of the removal of Lieutenant General Abdul-Wahab al-Saaedi, admired for his nationalistic approach in the military campaign against the Islamic State (IS), from his position as commander of the Counter-Terrorism Service and his demotion to a lower post at the Ministry of Defence. The marginalisation of al-Saaedi enraged many Iraqis. It seemed that all these factors accumulated, leading up to the protests explosion on October 1 (Mustafa, 2019).

In a similar fashion to the Arab Spring protests, the Tishreen revolution came in the wake of a social media campaign mobilising people to take to the streets in a large anti-government protest. Contrary to previous episodes of demonstrations, famous activists were not involved in this campaign. Rather, the mobilisation was led by new faces- mainly Shia youth- who did not appear affiliated with any political party. By late September, they were rallying for a 'revolution' on their Facebook pages. For instance, Muhammed Habib, one of the early 
protestors to be shot dead, wrote on his Facebook page on September 30 that 'It will be a huge public revolution in Baghdad...The date will be October 1. Labeik ya 'Iraq [Here we come, Iraq]...We will take to the streets protesting ... Enough silence about what's going on in Iraq. We cannot just watch Iraq being destroyed when we have armies of jobless and poor' (Habib, 2019).

The Tishreen uprising occurred in two stages: on October 1, 'the spark' and then on October 25, 'when the spark [had] become a Revolution' (Lovotti and Proserpio, 2021: 647). In the first stage, protestors borrowed from Arab Spring uprisings' famous slogan 'The People Want to Overthrow the Regime'. Raising this slogan for the first time marked a crucial change in protests movements' demands, departing from previous calls for mere reform (Nadhmi, 2020). It seemed that the new rhetoric prompted authorities to securitise the protestors as a threat (Neo, 2020) and alienate them from Iraqis. For this purpose, the spontaneous and peaceful protest was met with 'deadly force' using snipers and live fire and a campaign of harassment and intimidation (Amnesty, 2019b). Authorities also imposed an internet and media blackout to cover the repression and undermine the protests (Chulov, 2019). On October 8, demonstrators decided to suspend the protests to commemorate Imam Hussein's Arba'een. ${ }^{5}$

On October 25, the protests resumed and quickly became the most influential social movement in the country's recent history (Lovotti and Proserpio, 2021). For months, demonstrators occupied and reconstructed protest spaces, mobilising people, reconfiguring new identities and imagining alternative realities (Tunali, 2018). As discussed earlier, the call for a homeland and a system overhaul circulated new narratives that defied the legitimacy of the post-2003 political system and reclaimed a collective Iraqi identity (Mustafa, 2019; Hasan, 2020; Nadhmi, 2020). This does not mean that the Shia identity of the demonstrators

\footnotetext{
${ }^{5}$ Arba'een marks forty days following the Day of Asura in which Hussein Bin Ali, prophet Muhammed's grandson, was killed during the Battle of Karbala.
} 
was kept invisible. Instead, the two identities were integrated separately from Islamist ruling parties and the Iranian regime's version of Shiism. Imam Hussein flags, for instance, were juxtaposed with the Iraqi flag, freeing a revolutionary symbol from the control of the ruling parties, which have long claimed to represent it (Nadhmi, 2020).

The violent crackdown, assassinations and intimidation have never stopped. According to international organisations, hundreds were killed, and thousands were injured (See Amnesty, 2020). The use of force coincided with a deliberate disinformation campaign, seeking to destabilise and undermine the protests' narratives by demonising the demonstrators and their supporters (Mustafa, forthcoming in 2021). The repression and the ongoing assassination campaign against Iraqi activists and journalists partially contributed to fragmenting and weakening the uprising, but local protests continued to erupt at several points in 2020 (Lovotti and Proserpio, 2021). ${ }^{6}$ Although protestors' grievances were not addressed, the uprising led to unseating the Adil Abdul Mahdi government and reforming the elections law (International Crisis Group, 2021). Moreover, the uprising seems to have produced a political influence as several political parties affiliated with Tishreen have been founded. Some have participated in the latest early parliamentary elections held on October 10 2021, winning a few seats (Rasheed and Davison, 2021). Other activists, on the other hand, have decided to boycott the elections for many reasons, including the absence of accountability and shortcomings in the electoral system itself, and build an opposition base that would 'continue to call for the overhaul of the political system from the outside' (Alkhudary, 2021). ${ }^{7}$

Over the past two years, Iraqi youth have commemorated the uprising on the ground and virtual spaces, re-circulating its main slogans and chants (See Aljazeera, 2021). The new

\footnotetext{
${ }^{6}$ For a discussion of the factors that undermined the Tishreen uprising, refer to the latest report issued by the International Crisis Group Iraq's Tishreen Uprising: From Barricades to Ballot Box I Crisis Group.

${ }^{7}$ The latest elections have witnessed another low turnout due to the boycott movement (See Rasheed and Davison, 2021).
} 
narratives have become a referent point for Iraqis. The last section in this paper offers an indepth analysis of five powerful chants, their origins, and narratives.

\section{The narrative of belonging and sacrifice}

Many of Tishreen uprising slogans and chants underlined a sense of belonging to Iraq and people's sacrifices for a better country. One particular chant that was sung every Sunday vividly recalled that narrative. Sundays witnessed the participation of large crowds of university students in Tahrir Square in Baghdad and other protest squares in the south. Indeed, students played a remarkable role during the Tishreen protests, also known in Iraq as the Students' Revolution. Sunday is a working day in Iraq, and students' participation in the protests meant they were simultaneously striking by boycotting their classes, whether in secondary schools or universities (Ibrahim, 2019). As the students entered the tunnel leading to Tahrir square, they sang the Iraqi National Anthem, followed by the following chant (See Figure 1):

'Haya shabak ya watan, haya, dhahat bidamha wa rufa't arraya' [These are your youth, oh our homeland, who have sacrificed their blood and raised your flag].

\section{Figure 1: Students in the tunnel leading to Tahrir Square in $\operatorname{Baghdad}^{8}$}

\footnotetext{
${ }^{8}$ See هاي شبابك ياوطن هايه هاي بناتك ياوطن هايه هاي طلابك ياوطن هايه"من نفق التحرير -.... YouTube
} 


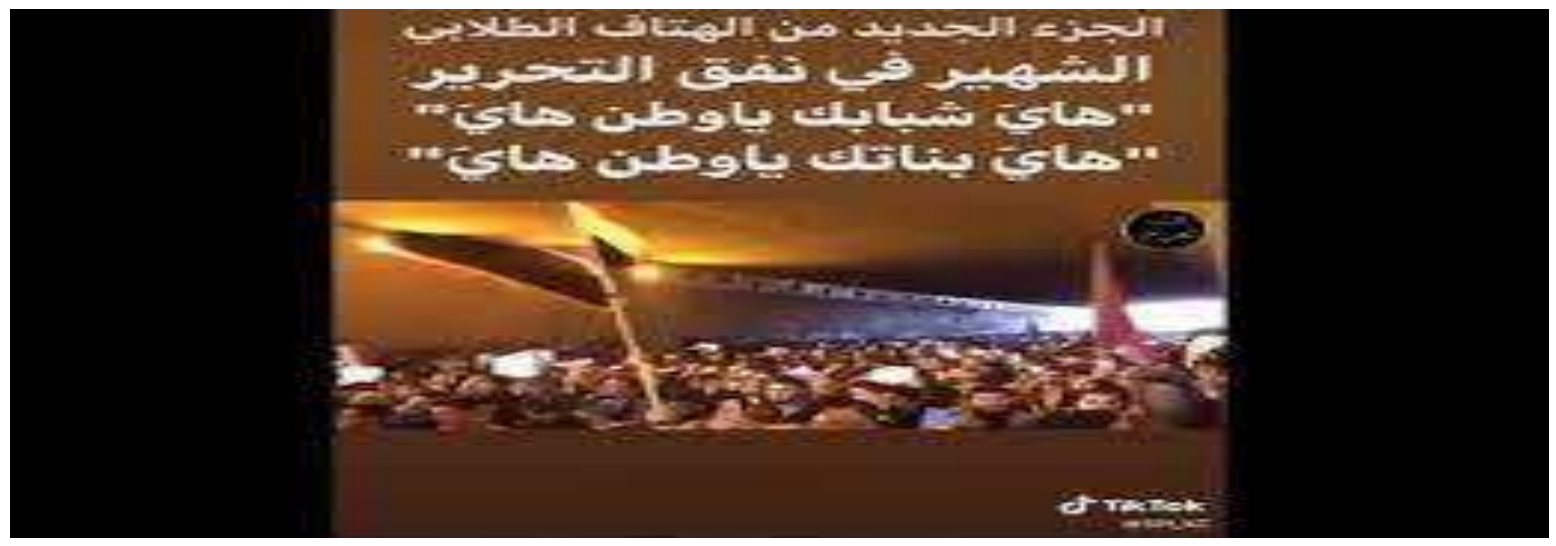

The chant persuasively reaffirmed the national identity of the young protestors, their sense of belonging to their country, and their sacrifices. The repetition of haya [these are] in the first line helped fulfil 'emotional, artistic, ritualistic...and rhetorical functions' (Al-Khafaji, 2005: 6). Moreover, this rhetorical device can convince others and construct new identities (Reisigl, 2008). The young protestors emphasised that they first and foremost identified as Iraqis, pushing away other secondary identities. The sacrifices here refer to those demonstrators killed by snipers' bullets, grenade stunts, or live ammunition by security forces, as well as to those activists assassinated by militias. They may also allude to those who fought IS and the civilians killed by the latter and al-Qaeda before. Taking into the streets was another sacrifice and act of defiance because students knew their livers were in real danger.

Notably, this chant first surfaced in 2012 as a religious inshooda praising Fatima, Prophet Muhammad's daughter and wife of Ali bin Abi Talib, Muhammad's cousin, fourth caliph, and the first Shia Imam (Kashani-Sabet, 2005). ${ }^{9}$ The inshooda was based on a Shia poem representing the portrayal of Fatima in Shiism as 'an exemplar of chastity and religiosity for women' (Lammens 1912:133 cited in Kashani-Sabet, 2005: 2). It was later adapted by supporters of Muqtada al-Sadr, hailing members of the Peace Brigades armed group founded by al-Sadr in 2014, allegedly to support Iraqi security forces during the battle against IS by

9 - أسرني شو كج للشاعر كريم مهذي الزيداوي 9 - 9 
protecting Islamic and Christian Shrines (France24, 2014). Its lyrics were: 'Haya saraya ibn al-sadr haya, dhahat bidamha wa rufaat alraya. Haya rijalak ya Muqtada haya, lil mot nubqa wiyak wafaya' [These are the members of al-Sadr's son brigades (in reference to Muqtada and the Peace Brigades armed group). They have sacrificed their blood and raised the flag. These are your men, Muqtada. We will remain loyal to you till death]. ${ }^{10}$ The narrative constructed by this chant radically differed from its altered version. It underscored an allegiance to al-Sadr, reinforcing the identity of the Sadrist movement and their unlimited support to their leader. Al-Sadr is revered by his followers partly due to the religious status of his father, Grand Ayatollah Muhammad Sadiq al-Sadr, who was assassinated by Saddam Hussein in the 1990s (Arraf, 2016). The chant captured his followers' loyalty: they were ready to sacrifice their lives not for Iraq per se but rather for al-Sadr. The flag here possibly referred to the Peace Brigades. ${ }^{11}$

The repetition of this chant in different contexts has helped in its wider dissemination, rendering it familiar to the protestors, mainly the Shia. The latest version redefined the dimensions of previous religious and political narratives by omitting the religious or sectcentred references and infusing the chant with an Iraqiness that persuaded the masses and rallied them around a collective cause. The chant was shortly rendered into a song about the protests. $^{12}$

\section{The narrative of sovereignty and anti-Iran dissent}

Tishreen protestors constantly chanted against foreign interference, particularly by Iran. Since 2003, Iran has penetrated Iraq, benefiting from several factors, including geographic proximity, economic and religious ties. Its influence has reached unmatched levels by

10 انشوده هاي سر ايه ابن الصدر هايه عندما يستشهي احد ابطال سر ايا السلام يفعلون ابطالنا في السر ايا هاكذا - YouTube

${ }_{11}$ In the latest elections, the Sadrist bloc won the majority of seats. See Iraq election: Nationalist cleric Moqtada al-Sadr claims victory - BBC News

12 - هايه شبابك ياوطن هايه أجمل إنشودة كرار الدلفي جديد وحصري 2019 - YouTube 
empowering several Shia militias under the pretext of fighting IS in 2014. These militias have been operating under the state-sponsored Popular Mobilisation Forces, also known as Hashed Shaabi ${ }^{13}$. Supporting key players within the Hashed has given Iran 'unique depth and leverage within Iraqi society and institutions' (IISS, 2019).

Although the protests were not chiefly about foreign interference, the growing outrage against Iran's meddling in Iraq has increased. During the demonstrations, this anger was communicated through many slogans and chants. One famous slogan was the following: 'Iran bara bara, Baghdad tubqa hura' [Iran out, Iran out! Baghdad remains free] (Al-ain, 2019). Like the last chant, the repetition of bara [out] was a rhetorical device employed to stress the demonstrators' denunciation of Iran's involvement in the country and their aspirations to see Baghdad and, by extension, Iraq free from its dominance.

Anti-Iran dissent and the call for sovereignty were enhanced when protestors in Baghdad and several southern provinces performed war songs from the Iran-Iraq War era, including the enthusiastic war ihzooja Mansoora ya Baghdad [May you be triumphal, oh, Baghdad]. ${ }^{14}$ Another song called $\mathrm{Ya} g a^{\prime}$ trabij kafoori [Our land, your soil is camphor] was altered by young Iraqi singers after modifying its lyrics to fit the context of the protests, taking out any reference to Saddam Hussein or the war with Iran. For instance, the line that called for fighting on the battle front was changed into hailing Iraqis' presence in the protests squares. ${ }^{15}$ The demonstrators frequently performed the newly revised song. For instance, it was played following a World Cup football qualifying match between Iraq and Iran to celebrate Iraq's 21 win over Iran. Crowds of protestors gathered in Tahrir Square in Baghdad to watch the game on a big screen. They danced, played music, and beat drums celebrating the second goal scored minutes before the game ended (The New Arab, 2019). Thousands then took into

\footnotetext{
${ }^{13}$ An umbrella organisation composed of pre-existing and new militia groups (mostly Shia). Hashed was formed in 2014 in response to the fatwa issued by Ali al-Sistani, Iraqi Shia most influential Marja' to fight Islamic State. 14 See $1 / 1 /$ / منصورة يا بغداد من ساحة التحرير 9 - YouTube

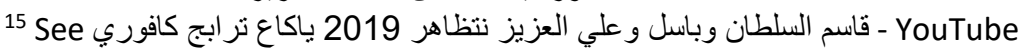


the streets to celebrate the win amid fireworks and music and, more significantly, to send political messages to Iran and its proxies in Iraq. This example demonstrates the relationship between performances and politics. Activists engaged with artistic strategies (Refer to Tunali, 2018) to subvert the hierarchal structures of power, build connections among the protestors and resist Iran's growing influence in Iraq.

Performing war songs constituted a diatribe against Iran. Diatribe is purposefully employed to 'shock' (Windt Jr, 1972: 8), attracting people's attention and reorganising their perspectives. Several activists told the press they hoped to motivate others to join the demonstrations after the violent crackdown caused their momentum to dwindle (The New Arab, 2019). In other words, Iraqi protestors appeared to strategically draw on shared cognitive and cultural schemas (Rattlif and Hill, 2014) by choosing a familiar song that restored an anti-Iran sentiment whilst attempting to disconnect it from its original war and Baathist context through reframing. The latter represents a strategic move 'consciously initiated in order to present a narrative in a certain light', redefining its features (Baker, 2006: 167). The process of reframing reconstructs new realities (Baker, 2006), wherein new perceptions are established and new responses are expected. Drawing on war songs was controversial since they were fuelled by violent and tribal rhetoric that contradicted the peaceful nature of the protest (Sabah, 2019).

It came as no surprise, therefore, that both the Iranian regime and Iran-backed militias were enraged. They started to escalate their existing antagonistic narrative against the protestors, labelling them as 'Baathists', 'gangs' or 'jokers' in their media outlets and news reporting (Mustafa, forthcoming in 2021). In particular, in reference to the 2019's movie (Joker), the joker has been constantly used as a pejorative label to demonise the protestors and discredit 
their movement. ${ }^{16}$ The securitisation of the protestors as a threat prompted them to respond in more powerful performances denying these labels and reclaiming the legitimacy of their movement. The 'moral shock' of the violence (Jasper, 1997) induced an emotional response of rebelliousness. At the same time, they insisted on their anti-Iran position. For instance, in southern Dhi Qar, a crowd of demonstrators chanted:

Ma rihbatna alsawtiyat...Bina 'nad shruqiya

[We have not been frightened by the sound bombs. We have the stubbornness of the southern people].

Nirja' nokaflak hosaat... Wihna nsakt alsawtiya

[We would always gather and chant, and we would silence the sound bombs].

Ma nitraja' la hayhaat... Khal tisma'na alhizbiya

[We will never back off. No way. Let all parties hear us!]

Iee wala...iee wala, wisma' dhi qar

[Oh, by God, oh by God. Listen to Dhi Qar!]

Min kul shari', min kul bab

[From every street, from every door]

Nitla'ma nirdha bi ahzab

[We go out, and we will never be pleased by parties]

Iee wala...iee wala, bina 'nad shruqiya

[Oh by God, oh by God, we have the stubbornness of the southern people].

Wakt alsakta, ana lisan...wana m'lim alhuriya

[At the time of silence, I am the speaking tongue. And I am the freedom teacher]. Isma'wiskut ya batran...wa'lik bi ithnak tarjiya

\footnotetext{
${ }^{16}$ The label came into circulation following the use of images depicting the Joker character amid protestors in Baghdad. The images were produced and disseminated by an Iraqi graphic designer(Bedirian, 2019).
} 
[Listen and be silent, you disgraceful, and keep this in mind like you would put a stud on your ear!]

Mu ba'athi min ashtim Iran...An'al abu alba'thiya

[I am not a Baathist when I curse Iran...Screw Baathism!].

Hur $w$ rafidh lil asnam

La Iran a wla Saddam

[I am free, and I refuse idols

Be it Iran or Saddam].

Ana mu'lim lil huriya

[I am a teacher of freedom].

This long chant had sound, rhythm, loud and musical clapping. It constituted an energetic and fervent performance that reiterated the protestors' fearlessness, solidarity and determination. While the lyrics were original, the performance imitated Ashura religious rituals, commemorating the death of Imam Hussein, Prophet Muhammad's grandson, and often known as 'Husseini marches'. During these marches, crowds of pilgrims gather to recite religious slogans written on a billboard held by a person in front of the masses (Hejja, 2019). The significance of framing the political performance with a religious practice known among Shia Muslims was two-fold. First, it was rich with symbolism because it reaffirmed the identity of the crowd as Shias who rejected their Shia rulers. Second, it was a tool of gathering the support of those who might have been hesitant to join the protests. Its poetic lyrics involved collective and implicit Hija [insult poetry] without naming a particular target. Instead, it generally used parties to address those in power who were repressing the protestors. Herein lied its impact: in its collectiveness. As Colla (2013: 43) describes, Hija represents 'a political weapon [that] strikes at the legitimacy and rectitude of the powerful'. The protestors were refusing all parties whilst reiterating their anti-Iran dissent. 
Disassociating themselves from Saddam Hussein and the Baathists, they reclaimed their legitimacy and identity as 'shruqiya'- people from the south of Iraq (Muhyi and Ali, 2021). According to late prominent Iraqi sociologist Ali al-Wardi, the term goes back to the Sumerian era when it meant the 'original citizen' (Al-Wardi cited in Hasan, 2015). Historically, the adjective began to acquire derogatory meanings when Middle Euphrates tribes primarily used it in a contemptuous sense to offend tribes living on the Tigris River to their east (Al-Wardi, 1956: 161). According to Hasan (2015), the term has turned into a political and racist vocabulary to label the southern Shia population in Baghdad and elsewhere in the south. By reclaiming their identity in its original positive sense, the protesters established 'group solidarity' (Coles, 2016: 425) and reversed the dominant discourse (Foucault, 1978: 101).

Invectives are not without consequences (Colla, 2013). On November 28, a few days following Dhi Qar insult performance, a range of security forces attacked the protestors in Nasiriyah, the provincial capital of Dhi Qar, reportedly killing 25 persons and injuring many more (Amnesty, 2019b). The assault is known in Iraq as Al-Zaytoon [Olive] Bridge massacre in reference to the bridge where the live ammunition took place (Teller Report, 2020). Nasiriyah massacre prompted people from other provinces, including from the west and north of Iraq, to march into the streets, condemning the killings and supporting the demonstrators and Tishreen movement as a whole, as discussed in the following section.

\section{From Basra to Nasiriyah to Tikrit: The narrative of solidarity}

In early December, many young protestors marched in several provinces in the west and north of Iraq, including Mosul, Tikrit, and Anbar, in solidarity with Nasiriyah. Moreover, University of Mosul and Tikrit University students held vigils mourning the victims. They wore black clothes and chanted Tishreen slogans. Nevertheless, the students faced immediate repression and could not continue their protests (Abbas, 2020). Even though several Sunnis, 
Kurds, Ezidis and Christians joined the protestors in Tahrir square in Baghdad (Abbas, 2020), this was the first time Sunni Iraqis protested in their provinces. Prior to these demonstrations, Sunnis chose not to fully engage with the Tishreen movement for several reasons, mainly related to fears of accusations by the government of supporting IS or pursuing its agenda to retake liberated provinces (Badawi, 2020). More importantly, Sunni activists were threatened, arrested and intimidated by parties and security forces (Al-Saray, 2020), which proved that the protests posed an existential threat to all ruling parties. Clamping down on the protestors was necessary to maintain the status quo.

Sunnis participation in the Tishreen movement marked a crucial cross-sectarian moment during which the national identity prevailed above all other secondary identities. One of the main slogans chanted by crowds of the students in both Tikrit and Anbar was inspired by the previously mentioned chant associated with Basra 2018's protests: nmut 'ashara, nmut miya, any qaful 'al qadhiya [10 of us would die, or 100 of us would die, I won't give up the cause]. The modified copy was: nmut 'ashra, nmut miya, yubqa sot al-Nasiriyah [10 of us would die, or 100 of us would die, Nasiriyah's voice shall remain]. But these were not the only two renditions. The two versions were variants of an older slogan, which could be traced back to a video posted on YouTube in 2010 in which a crowd of Shia Muslim pilgrims commemorated the death of Imam Hussein, chanting: nmut 'ashra, nmut miya, yubqa sot al-ja'afariya, qulo 'na rafidhiya, yubqa sot al-ja'afariya [10 of us would die, or 100 of us would die, the Jaafari (Shia) voice shall remain. Call us Rafidhi (rejecters), the Jaafari (Shia) voice shall remain]. ${ }^{17}$ The 2010's chant foregrounded a Shia identity embedded within a narrative of sectarian tension. Rawafith or rafitha, ${ }^{18}$ literally meaning rejecters, is an antishiism religiously-laden label that some Sunni or Salafi extremists have increasingly used

\footnotetext{
17 See 3 - يبقى صوت الجعفريه YouTube 18 Likewise, there are other derogatory terms in Shia discourse used to label Sunnis, including the term 'nasibi' (defamers of the House of the Prophet-i.e. the line of Shi'a Imams) (Haddad, 2011: 191-92).
} 
since 2003 as a frame for a 'sectarian dogma', excluding Shias from Muslims (Haddad, 2013; Haddad, 2014: 13). To undermine its pejorative sense, some Shias have adopted the term as a 'badge of honour' (Haddad, 2013), as depicted in the example above.

By replacing the 'Jaafari' with 'cause' in the context of Basra's 2018 protests, the slogan completely transformed the above narrative and its features into a narrative of a common cause. Changing 'cause' to 'Nasiriyah' or 'Dhi Qar' in the context of the Tishreen uprising highlighted the resistance of the demonstrators despite the ongoing violence they were facing. Chanting the latest adaptation of the slogan by Sunni protestors circulated a narrative of solidarity with Nasiriyah. But it was more than just a chant. Videos disseminated from Tikrit, for example, portrayed a group of demonstrators beating on their chests: a mourning ritual often practised by Shia Muslims during Ashura (Abbas, 2020) (See Figure 2). According to Abbass (2020), chest-beating in Sunni majority areas was seen as an example of dominance by Shia political parties over less powerful Sunni groups in what represented an unfair political equation devoid of any national meanings (Abbas, 2020: 57). I argue that performing chest-beating by Shia militias in Sunni areas incites sectarian sentiments because it enforces a Shia identity over Sunni communities.

In contrast, enacting this body movement by Sunnis was emblematic of a collective protesting attitude against the government practised by both Shias and Sunnis (Abbas, 2020). This symbolic performance, its filming and posting on social media sites, brings us back to the point of scripted performances. Sunni demonstrators made a strategic choice to draw on a religious ritual often practised by Shia Muslims, delivering a message of support with Nasiriyah's demonstrators, endorsing Tishreen narratives and concurrently challenging the government and ruling parties. 
Figure 2: Tikrit University Students Beating their Chests ${ }^{19}$

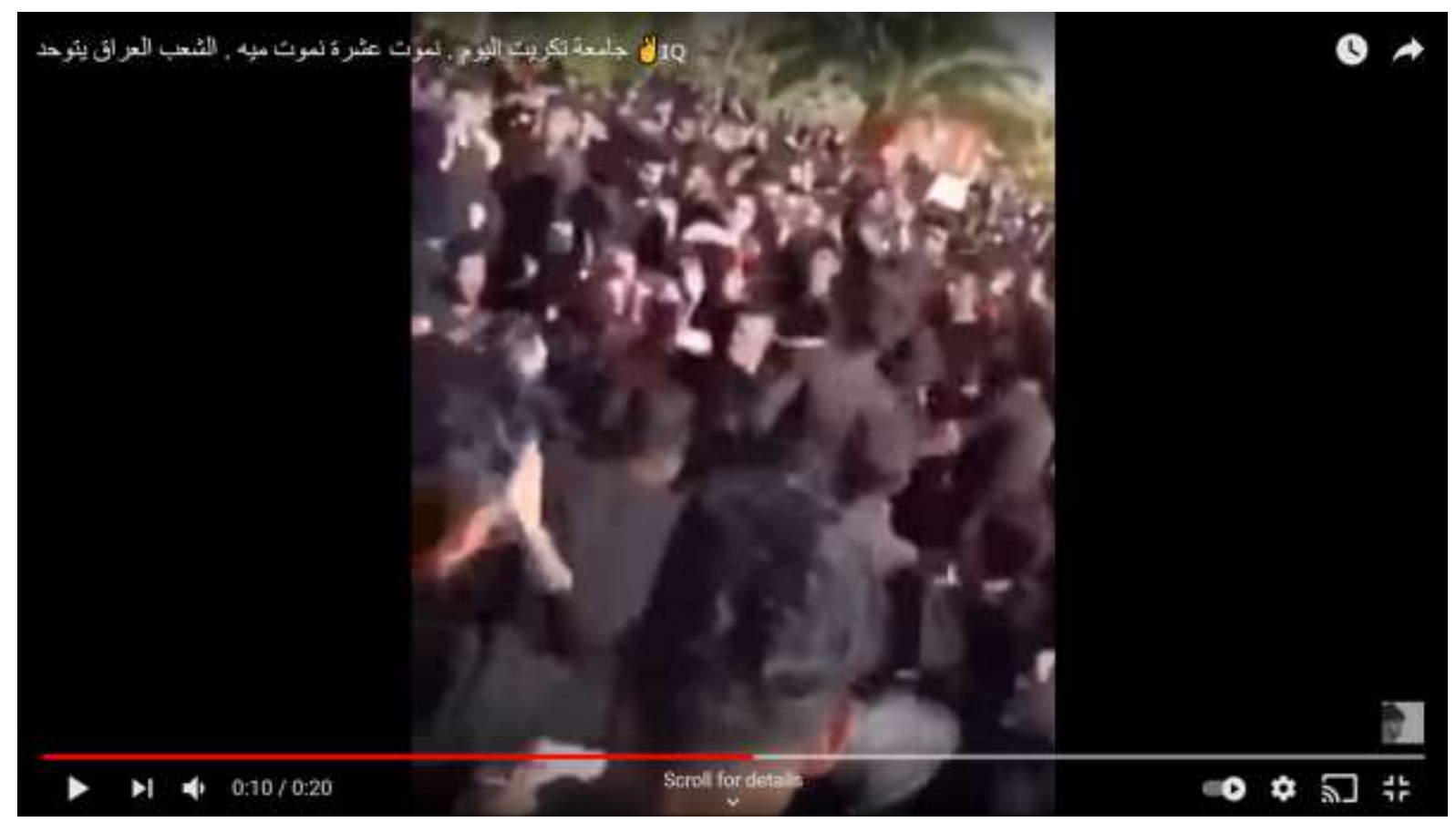

\section{The narrative of a non-Islamist rule}

The last section in this paper explores another longer chant sung by a group of Nasiriyah's protestors in early December 2019 and was another invective targeting political parties, particularly Shia rulers. Like the previous Nasiriyah's tirade, the current one found its roots in the aesthetics of Ashura rituals (See Figure 3):

\section{Nireedlina qaid mu mithil hay alqumamat}

[We want a leader, not like these trash leaders].

Nireedlina qaid mu min thiyool al safaraat

[We want a leader who is not a tail of embassies].

Ma nireed qaid ja'fari, taliha yitla' sarsary

[We don't want a Jaafari leader, who would turn to be corrupt].

\footnotetext{
${ }^{19}$ See - نموت عشرة YouTube
} 
[We want an honourable leader. We no longer care about religions].

\section{Figure 3: Crowd of Dhi Qar demonstrators chanting. ${ }^{20}$}

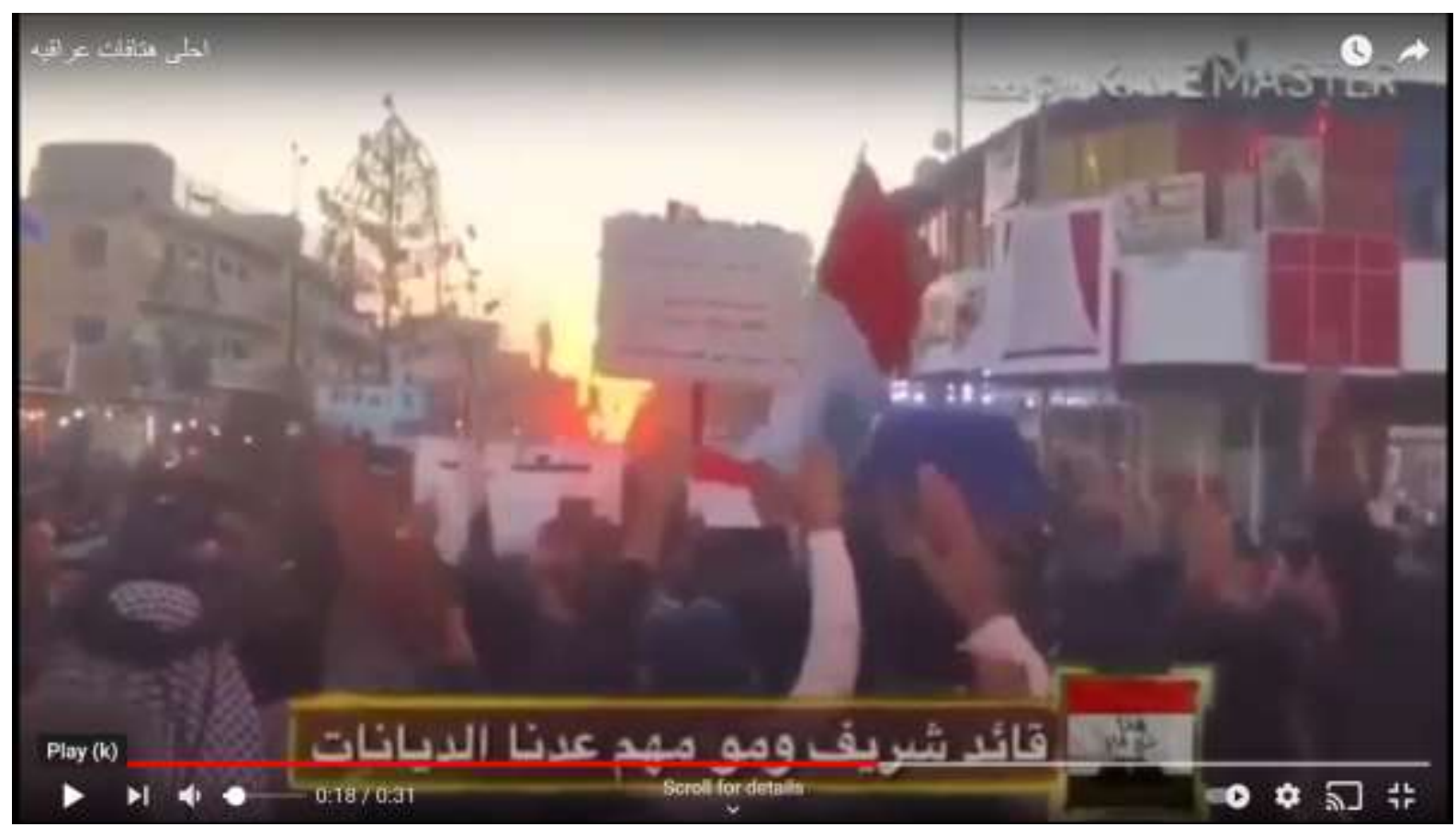

A few observations could be made here. Firstly, the lyrics implicitly reversed an earlier slogan that had first come out during the 1991's Intifada by Shia Arabs and Kurds against Saddam Hussein and the Baathists: Maku wali ila Ali, win reed qaid ja'afari [There should be no commander except Ali (in reference to Ali bin Abi Talib, Prophet Muhammad's cousin and the fourth caliph), and we want a Shia ruler] (Ibrahim, 2014). The slogan mirrored the Shia population's desire to be ruled by Shia leaders who can follow Ali bin Abi Talib's approach in governance, which is claimed to be just and fair (Hasan, 2019). It was, then, widely exploited and redeployed by post-2003 politicians, religious leaders, clerics and their supporters to construct a narrative of Shias' righteousness to rule. Since then, it was met with controversy. For the most part, the slogan has been criticised for its sectarian and divisive

20 See - احلى هنافات عر اقيه YouTube 
language, feeding divisions among Iraqis and distancing all other communities, including Sunnis and non-Muslims (Al-Khayoun, 2006). Ibrahim (2014) went further to argue that even during the 1991's uprisings, the slogan failed to establish a united Iraqi identity and rhetoric, triggering a sectarian narrative instead.

Secondly, and consequently, Nasiriyah's chant directly rejected Shia politicians' politicised narratives of victimhood and their right to rule. It furthered a narrative of a non-Islamist or arguably a secular rule. Secular activists participated in Tishreen protests (Neurink, 2019). Their presence is part of a larger secular trend among groups of young people in Iraq and the Middle East region. According to 2019's polling surveys by the Arab Barometer, 'There has been a decline in religious faith and trust in religious parties across the Middle East and North Africa' (Habtom, 2019). ${ }^{21}$ It is important to note that there was no consensus among Tishreen protestors on a call for a secular political system. Rather, it was contested by diverse groups of protestors and activists. Communicating such demand through a religiously and culturally inspired performance possibly aimed to embolden the participants and others to rise against Islamists.

Thirdly, the insult poetry was evidenced by the use of three words: qumamat [trash], sarsary [corrupt or immoral] and thail [tail]. The three slang words collectively insulted all those who have ruled Iraq post-2003. The third one, in particular, gained circulation among protestors shortly after the protest erupted. It was first adopted to attack the political class with allegiances to Iran. Thail or thiyol [tail or tails] were two labels constituting a diatribe to shame the ruling class and Iran-backed militias for not being loyal to Iraq and counter the derogatory label the 'joker' used to charge protestors and activists of being US agents. In this sense, tail(s) has created a counter-narrative whereby those in power are accused of being Iran's agents. The label has been extended in its use to target anyone

\footnotetext{
${ }^{21}$ Also, see The Arab world in seven charts: Are Arabs turning their backs on religion? - BBC News
} 
who defends the ruling class and Iran-backed armed groups. Both the 'joker' and 'tail' have been contesting, escalating a polarised narrative and establishing two opposing identities. Neither label has been able to push away the other or to dominate the space in total.

Fourthly, the schism between the Shia population and their leaders could not be clearer: the new generation could no longer be deceived by past narratives invoked by the 1991's slogan. The demonstrators vividly said that their rulers' religious or sect backgrounds no longer carried any weight or significance. Together, they discredited the political class by saying that their primary demand was for a good leader to rule. It made no sense whether the leader was Shia so long as he would fail the people. His religious beliefs did not matter. The last chant distanced Shia protestors from their leaders' narrative of a legitimate Shia rule and identity, revealing an aspiration for a non-Islamist or even secular governing system.

\section{Conclusions}

Tishreen chants did not operate in a vacuum. They were influenced by diverse performances revised by the protestors to produce new shared narratives. Stimulated by a song of a religious nature, the first chant illustrated the reclamation of Iraqi identity and nation. Chanting new versions of the Iran-Iraq war articulated the protestors' resentment with Iran's role in Iraq and their desire to see Iraq free from foreign interference. Drawing from Asura rituals showed the appropriation of religious performances to heighten an Iraqi Shia identity and a denial of the ruling parties, their sectarian discourse, Islamism, Baathism and Iran. In Sunni provinces, performing Shias' practice of chest-beating could be seen as emblematic of the solidarity with Tishreen and its narratives. Arguably, the impact of these chants was far more transcending than their earlier adaptations. But will they resist change? This question recalls Tilly's argument about performances and their incremental and limited transformation. Slogans or chants would constantly evolve. New contexts and different 
participants will enable their rendition. For example, a new video disseminated on social media displays a group of the Popular Mobilization Forces chanting an adjusted edition of the first chant examined in this paper. ${ }^{22}$ Replacing Watan [home] with hashed [These are your youth, oh our hashed] not only drops Iraq from the narrative but also constitutes a different identity and sense of belonging. Does the latest version have the same influence as the former Tishreen chant? Previous research leaves this question unanswered. My paper has demonstrated that while slogans or chants keep changing, they vary in their influence according to the broader narratives they help invoke. Tishreen chants will be remembered for their collective narratives centred around Iraq. Other adaptations may be of a less impact limited to those groups that subscribe to their narratives.

\section{References}

Abbas A (2020) Alrumooz alhusseiniya alshi'iya wa wadhaifuha alwatinya fi alihtijajat aliraqiya: Muqaraba thaqafiya [Husseini Shia Symbols and their National Functions in the Iraqi Protests: A Cultural Approach]. In: Hasan H and Nadhmi F K (eds) Alihtijajat altishriniya fi aliraq: Ihtidhar alqadeem wa isti'saa aljadeed [October Protests in Iraq: The Old is Dying and the New Cannot be Born]. Baghdad: Al-Mada Institute, pp.47-63.

Al-ain (2019) 'Iran bara..Baghdad hura'..Hutafat tahuz almudun aliraqiya [Iran out..Baghdad free..Chants shaking Iraqi cities] [Online]. Available at: "إفات تهز المدن . .إن برا.. بغداد حرة العر اقية (al-ain.com) (accessed 13 April 2021).

Al-Haq FA and Hussein A (2012) The slogans of the Tunisian and Egyptian revolutions. In: 42nd Colloquium on African Languages and Linguistics (CALL), Leiden, The Netherlands, 27-29 August 2012. Leiden, The Netherlands: Leiden University Centre for Linguistics.

\footnotetext{
${ }^{22}$ See Husam Sobhi on Twitter: "@M Balsam هسه صارت هاي شبابك ياحشد هاية https://t.co/1aPJumgDRx" / Twitter
} 
Aljazeera (2021) Iraqis march in Baghdad to mark protests anniversary [Online]. Available at: Iraqis march in Baghdad to mark protests anniversary | Protests News | Al Jazeera (accessed 22 October 2021).

Ali Z (2021) From Recognition to Redistribution? Protest Movements in Iraq in the Age of 'New Civil Society'. Journal of Intervention and Statebuilding: 1-15.

Al-Khafaji R (2005) Variation and recurrence in the lexical chains of Arabic and English texts. Poznan Studies in Contemporary Linguistics 40: 5-25.

Al-Khalidi M (2021) Alhosa alsha'biya fi aliraq dirasa wa nusus [Public chant in Iraq: A study and texts] [Online]. Althaqafa Alsha'biya [Pobular Culture] 34. Available: الثقافة الثعبية (folkculturebh.org) (accessed May 15 2021).

Al-Khayoun R (2006) Al'iraq..«makw waly ila 'aly.. wn'ryeedd qa'ed j'afary»..! [Iraq.. There is no ruler but Ali and we want a Jaafari leader] [Online]. Available at: العر اق..(ماكو ولي إلا علي.. ونُريد قائد جعفري《..! - رشيد الخيون (aawsat.com) (accesses 2 August 2021).

Alkhudary T (2021) From Muhasasa to Mawatana: The election boycott movement and prospects for effective democracy in Iraq [Online]. Available at: From Muhasasa to Mawatana: The election boycott movement and prospects for effective democracy in Iraq | Middle East Centre (lse.ac.uk) (accessed 20 October 2021).

Al-Saray A (2020) Al'Iraq yahatj... madha 'an almanatiq almuhararh min «da'ish»? [Iraq is protesting...What about areas liberated from Daesh] [Online]. Available at: العراق يحتج... ماذا عن (المناطق المحررة من 》داعش«؟ | الثرق الأوسط (aawsat.com) (accesses 2 August 2021).

Al-Shams K H (ed) (2021a) Alkhitab althair lsanya wnaqdya: dirasat fy shi'arat intfadat tishryn al'raqiyah [The revolutionary spoken and critical discourse: Studies of October Uprising slogans]. Baghdad: Dijla Academic Publisher. 
Al-Shams KH (2021b) Shi'arat altaghyir althaira: Dirasa fi tahlil alkhitab [Revolutionary slogans of change: A study in discourse analysis]. Amman: Academic Book Centre.

Al-Sowaidi B, Banda F and Mansour A (2017) Doing politics in the recent Arab uprisings: towards a political discourse analysis of the Arab Spring slogans. Journal of Asian and African Studies 52(5): 621-645.

Al-Wardi A (1965) Dirasa fi tabi'at almujtama'a aliraqi [A Study of the Nature of Iraqi Society]. Beirut: Dijla and al-Furat Library.

Amnesty (2019a) Iraq: Deadly sniper attacks and intimidation as protesters face intensifying crackdown [Online]. Available at: Iraq: Deadly sniper attacks and intimidation as protesters face intensifying crackdown - Amnesty International (accessed October 25 2021).

Amnesty (2019b) Iraq: Eyewitness describes 'street filled with blood' as at least 25 protesters killed in security force onslaught [Online]. Available at: Iraq: Eyewitness describes 'catastrophe' as at least 15 protesters killed in security force onslaught | Amnesty International (accessed May $202021)$

Amnesty (2020) Iraq 2020 [Online]. Available at: Everything you need to know about human rights in Iraq 2020 | Amnesty International Amnesty International (accessed May 20 2021).

Andrews M (2004) Opening to the original contributions: Counter-narratives and the power to oppose. In: Bamberg MB Bamberg and Andrews M (eds) Considering Counter-Narratives: Narrating, resisting, making sense. Amsterdam: John Benjamins, pp.1-6.

Arraf J (2016) Muqtada al-Sadr's Revolution [Online]. Available at: Muqtada al-Sadr's Revolution Foreign Policy (accessed 22 October 2021). 
Atiya HAZ (2021) 'Unf alugha wa ma'rakat alafitat [The violence of language and the battle of banners]. In: Al-Shams KH (ed) Alkhitab althair lsanya wnaqdya: dirasat fy shi'arat intfadat tishryn al'raqiyah [The revolutionary spoken and critical discourse: Studies of October Uprising slogans]. Baghdad: Dijla Academic Publisher, pp.55-73.

Aulich, J (2019) Conclusion: Reflections on Protest and Political Transformation since 17891. In Duyvendak JW and Jasper JM (eds) The Aesthetics of global protest: Visual culture and communication. Netherlands: Amsterdam University Press, pp.269-288.

Badawi T (2019) Why Arab Sunnis are disengaged from Iraq's protests [Online]. Available at: Why Arab Sunnis are disengaged from Iraq's protests - Atlantic Council (accesses August 2 2021).

Baker M (2006) Translation and conflict: A narrative account. London: Routledge.

Bedirian R (2019) Meet Ahmed Shwqy, the man behind Baghdad's viral Joker battle images [Online]. Available at: Meet Ahmed Shwqy, the man behind Baghdad's viral Joker battle images | The National (thenationalnews.com) . (accessed February 15 2021).

Billig M (1991) Ideology and Opinions: Studies in Rhetorical Psychology. London, UK: SAGE.

Billig M (1995) Banal Nationalism. London, UK: SAGE.

Bitzer L (1981) Political rhetoric. In: Nimmo DD and Sanders KR (eds) Handbook of Political Communication. Beverly Hills, CA: SAGE, pp.225-248.

Butler J (2015) Notes toward a performative theory of assembly. Cambridge: Harvard University Press.

Carle Z (2021) The voice of the people? Echoes and quotations in the revolutionary slogans in Egypt. Mediterranean Politics 26(1): 55-73. 
Chulov M (2019) Internet blackout in Iraq as death toll from violent protests rises [Online]. Available at: Internet blackout in Iraq as death toll from violent protests rises $\mid$ Iraq $\mid$ The Guardian (accessed 15 January 2021).

Coles G (2016) The exorcism of language: Reclaimed derogatory terms and their limits. College English 78(5): 424-446.

Colla E (2012) The people want. MER 42(263). Available at: www.midanmasr.com/en/article. aspx?ArticleID=220 (accessed 12 July 2021).

Colla, E (2013) In praise of insult: Slogan genres, slogan repertoires and innovation. Review of Middle East Studies 47(1): 37-48.

Cornish C (2019) Brutal crackdown on Iraq protests echoes Saddam Hussein era [Online]. Available at: https://www.ft.com/content/fb5688c0-0d11-11ea-bb52-34c8d9dc6d84. (accessed 19 October 2021)

Denton R (1980) The rhetorical functions of slogans: Classifications and characteristics. Communication Quarterly 28(2): 10-18.

Foucault M (1978). The History of Sexuality, Vol. 1: An introduction. Trans. Hurley R. New York: Pantheon.

France24 (2014) alez'eyem aleshey’y Muqtada alsdir yaqtarih inesha' "saraya alsalam" lildefa' 'an almuqedsat aldyenyah [Shia leader Muqtada al-Sadr suggest to establish Peace Brigades to defend religious shrines]. Available at: للدفاع عن "سر ايا السلام"الزعيم الثيعي مقتدى الصدر يقترح إنشاء المقدسات الدينية (france24.com) (accessed 1 July 2021).

Grusin R. (2015) Radical mediation. Critical Inquiry 42(1):124-148.

Habib M (2019) Facebook post [Online]. Available at: Facebook (accessed October 10 2019). 
Habtom N K T (2020) Is the MENA Region Becoming Less Religious? An Interview with Michael Robbins [Online]. Available at: Is the MENA Region Becoming Less Religious? An Interview with Michael Robbins - Arab Barometer (accessed May 20 2021).

Haddad F (2011) Sectarianism in Iraq: Antagonistic Visions of Unity. Oxford: Oxford University Press.

Haddad F (2013) The language of anti-Shiism [online]. Available at: http://foreignpolicy.com/2013/08/09/the-language-of-anti-shiism/ (accessed March 23 2015).

Haddad F (2014) A sectarian awakening: Reinventing Sunni identity in Iraq after 2003. Current Trends in Islamist Ideology 17: 145-176.

Hasan B (2019) Kayf saraq "alhakm alja'fary" hilm alfqura' "biisim 'aly"? [How did the Shia ruler steal the dream of the poor under Ali’s name?] [Online]. Available at: الحاكم الجعفري"كيف سرق" ؟"اسم علًي"حلم الفقر اء بـ (ultrasawt.com) (accesses 2 August 2021).

Hasan H (2020) Alihtijajat altishriniya wa bunyat alsulta fi ali'iraq [October protests and the authority structure in Iraq]. In: Hasan H and Nadhmi F K (eds) Alihtijajat altishriniya fi aliraq: Ihtidhar alqadeem wa isti'saa aljadeed [October Protests in Iraq: The Old is Dying and the New Cannot be Born]. Baghdad: Al-Mada Institute, pp.21-35.

Hasan L R (2015) Warwar wa almi'dan [Warwar and the Marsh Arabs]. Available at: الكاردينيا - مجلة .

Hejja R (2019) Alahazyj al'iraqiyah.. tarykhha whadrha althawry fy naqd alhkam wmdyh almrah [Iraqi chants..their history and revolutionary presence in criticising rulers and praising woman]. Available at: الأهازيج العر اقية.. تاريخها وحاضر ها الثوري في نقد الحكام ومديح المرأ | Irfaasawtak (accessed 22 May 2021). 
Ibrahim A (2019) Iraq's striking students defiant amid unrelenting protests [Online]. Available at: Iraq's striking students defiant amid unrelenting protests | News | Al Jazeera (accessed 22 October 2021).

Ibrahim M A (2014) Makw waly ila 'aly.. wn’ryeedd qa'ed j'afary [There is no ruler but Ali and we مازن الثيخ ابر اهيم - ماكو ولي الا علي,ونريد حاكم جعفري :want a Jaafari leader] [Online]. Available at (ahewar.org) (accesses 2 August 2021).

IISS (2019) Iran's Networks of Influence - Chapter Four: Iraq [online].Available at: Iran's Networks of Influence in Iraq | Abu Mahdi al-Muhandis (iiss.org) (accessed August 12 2021).

International Crisis Group (2021) Iraq's Tishreen Uprising: From barricades to ballot box [Online]. Available at: Iraq's Tishreen Uprising: From Barricades to Ballot Box | Crisis Group (accessed: 20 October 2021).

Ismail S (2011) The Syrian uprising: Imagining and performing the nation. Studies in Ethnicity and Nationalism 11(3): 538-549.

Jakobsen R (1987) Linguistics and Poetics. In: Pomorska K and Rudy S (eds) Language in Literature. Cambridge: Harvard University Press, pp.62-94.

Jasper JM (1997) The art of moral protest. Chicago, IL: University of Chicago Press.

Kashani-Sabet F (2005) Who is Fatima? Gender, culture, and representation in Islam. Journal of Middle East Women's Studies 1(2): 1-24.

Kaul DK (2010) Continuing Place Discourse - Place Identity and Slogans. Available at: http://panunkashmir. org/blog/ecoculture/continuing-place-discourse-place-identity-andslogans (accessed 11 July 2021). 
Kress GR (2009) Multimodality: A social-semiotic approach to contemporary communication. London: Routledge.

Lahlali M (2014) The discourse of Egyptian slogans: From 'Long Live Sir' to 'Down with the Dictator'. Journal of Arab Media and Society 19: 1-14.

Lammens H (1912) Fatima et les filies du Mahomet. Rome: Sumptibus Pontificii Instituti Biblici.

Lovotti C and Proserpio L (2021) The October 2019 protest movement in Iraq. An Analysis of the 'early moments' of the mobilisation. Partecipazione e conflitto 14(2): 644-662.

Lu X (1999) An ideological/cultural analysis of political slogans in Communist China. Discourse and Society 10(4): 487-508.

Lu X (2004) Rhetoric of the Chinese Cultural Revolution: The Impact on Chinese Thought, Culture, and Communication. Columbia, SC: University of South Carolina Press.

Lüders M, Prøitz L and Rasmussen T (2010) Emerging personal media genres. New Media and Society 12(6): 947-963.

Mabon S (2017) 'Nationalist Jāhiliyyah and the flag of the two crusaders, or: ISIS, sovereignty, and the "Owl of Minerva". Studies in Conflict \& Terrorism, 40(11): 966-985.

Mahmoud M and Al-Rawi BJ (2019) The slogans of the Iraqi demonstrators demanding reform: Semiotics study. Journal College of Media ,University of Baghdad 46(3): 228-256.

Manabe N (2019) Women's march colloquy-chants of the resistance: Flow, memory, and inclusivity. Music and Politics 13(1): 1-19.

Miller CR (2015) Genre as social action (1984), revisited 30 years later (2014). Letras and Letras 31(3): 56-72. 
Muhyi AA and Ali NK (2021) Alfawail althaqafiyh wa'thrha fy alf'il aliqna'y fy alkhitab altishriny [Cultural drivers and their impact on the persuasive act in October's speech]. In: Al-Shams KH (ed) Alkhitab althair lsanya wnaqdya: dirasat fy shi'arat intfadat tishryn al'raqiyah [The revolutionary spoken and critical discourse: Studies of October Uprising slogans]. Baghdad: Dijla Academic Publisher, pp.259-275.

Mustafa B (2018) All about a home: The reasons for Iraq's protests [Online]. Available at: All About A Home: The Reasons for Iraq's Protests - EA WorldView . (accessed March 112021.

Mustafa B (2019) Violent crackdown against Iraq protests exposes fallacy of the country's democracy [Online]. Available at: Violent crackdown against Iraq protests exposes fallacy of the country's democracy (theconversation.com) . (accessed March 112021 ).

Mustafa B (Forthcoming in 2021) Tishreen hirak wa i'lam: Sardiyt Sira' [October's protest movement: Contested narratives). In: Aljafal O (ed.) Thawrat Tishreen fi al 'Iraq [October revolution in Iraq]. Berlin and Beirut: The Rosa Luxemburg Stiftung and Dar-alrafidain.

Nadhmi FK (2020) Fuqara alshiaa wa'iadat binaa alwatinya aliraqiya [Shia poor and the reconstruction of Iraqi nationality]. In: Hasan $\mathrm{H}$ and Nadhmi F K (eds) Alihtijajat altishriniya fi aliraq: Ihtidhar alqadeem wa isti'saa aljadeed [October Protests in Iraq: The Old is Dying and the New Cannot be Born]. Baghdad: Al-Mada Institute, pp.35-47.

Nassar MM and Al-Harahsheh AM (2020) A socio-pragmatic study of the Lebanese uprising slogans. International Journal of English and Education 9(3): 174-184.

Neo R (2020) Religious securitisation and institutionalised sectarianism in Saudi Arabia. Critical Studies on Security 8(3): 203-222. 
Neurink J (2020) Are Iraqi youths losing their religion? [Online]. Available at: Are Iraqi youths losing their religion? - Al-Monitor: The Pulse of the Middle East (accesses August 2 2021). Rasheed A and Davison J (2021) Cleric Sadr wins Iraq vote, former PM Maliki close behind officials [Online]. Available at: Cleric Sadr wins Iraq vote, former PM Maliki close behind officials | Reuters (accessed 22 October 2021).

Ratliff TN and Hall LL (2014) Practicing the art of dissent: Toward a typology of protest activity in the United States. Humanity and Society 38(3): 268-294.

Reisigl M (2008) Analysing Political Rhetoric. In: Wodak R and Krżyzanowski M (eds) Qualitative Discourse Analysis in the Social Sciences. Palgrave Macmillan, Houndmills, Basingstoke, Hampshire, pp. 96-120.

Robertson GB (2010) The politics of protest in hybrid regimes: Managing dissent in post-communist Russia. Cambridge: Cambridge University Press.

Rubin AJ (2019) Iraq in worst political crisis in years as death toll mounts from protests [Online]. Available at: https://www.nytimes.com/2019/12/21/world/middleeast/Iraqprotests-Iran.html. (accessed 22 October 2021).

Sabah M (2019) Thawrat tishryn walfn al'iraqy albadyl [October revolution and the alternative Iraqi art]. Available at: Jadaliyya - ثورة تشرين و الفن العراقي البديل (accessed 10 June 2021).

Sharp H (1984) Advertising Slogans of America. Metuchen, NJ: The Scarecrow Press.

Somers MR (1992) Narrativity, narrative identity, and social action: Rethinking English workingclass formation. Social Science History 16(4): 591-630.

Somers MR (1994). The narrative constitution of identity: A relational and network approach. Theory and Society 23(5): 605-649. 
Srour, I (2021) Ideological Schema and Legitimization of Voice in the Lebanese Revolution Slogans. Available at: Ideological Schema and Legitimization of Voice in the Lebanese Revolution Slogans - مجلة أور اق ثقافية (awraqthaqafya.com) . (accessed July 11 2021).

Teller Report (2020) A year after the olive bridge massacre .. The protesters in Iraq are commemorating the memory and insisting on accountability. Available at: A year after the olive bridge massacre .. The protesters in Iraq are commemorating the memory and insisting on accountability - Teller Report (accessed May 20 2021).

The New Arab (2019) Protesters in Iraq celebrate football win against Iran. Available at: Protesters in Iraq celebrate football win against Iran (alaraby.co.uk) (accessed June 15 2021).

Tilly C (2008) Contentious Performances. Cambridge: Cambridge University Press.

Tunali $T$ (2018) The Art of Resistance: Carnival Aesthetics and the Gezi Street Protests. ASAP/Journal 3(2): 377-399.

van Dijk TA (1997) What is political discourse analysis? In: Blommaert J and Bulcaen C (eds) Political Linguistics 11(1). Amsterdam, The Netherlands: Benjamins, pp.11-52.

Windt TOJr (1972) The diatribe: Last resort for protest. Quarterly Journal of Speech 58(1): 1-14. doi:10.1080/00335637209383096. 